\title{
Panhypopituitarism secondary to a solitary hypothalamic metastasis
}

\author{
Mark Ellul, ${ }^{1}$ Tobias Janowitz, ${ }^{1}$ Neil Burnet ${ }^{2}$
}

${ }^{1}$ Department of Oncology, Addenbrooke's Hospital, Cambridge, UK

${ }^{2}$ Department of Oncology, University of Cambridge, Cambridge, UK

\section{Correspondence to}

Dr Mark Ellul,

markalexellul@gmail.com

Accepted 4 May 2014
CrossMark

To cite: Ellul M, Janowitz $\mathrm{T}$, Burnet N. BMJ Case Rep Published online: [please include Day Month Year] doi:10.1136/bcr-2014204283

\section{DESCRIPTION}

A 50-year-old woman with breast cancer and widespread skeletal metastases presented with lethargy, weight gain and memory loss. Blood tests showed panhypopituitarism: thyroid-stimulating hormone $0.17 \mathrm{mU} / \mathrm{L}$ (0.35-5.5), free T4 $4.2 \mathrm{pmol} / \mathrm{L}$ (10 19.8), free T3 $1.2 \mathrm{pmol} / \mathrm{L}(3.5-6.5)$, luteinising hormone $<0.1 \mu \mathrm{mol} / \mathrm{L}$ (16-75 postmenopausal), follicle-stimulating hormone $<0.3 \mathrm{U} / \mathrm{L} \quad(21-140$ postmenopausal) and random cortisol $32 \mathrm{nmol} / \mathrm{L}$. Prolactin was also low at $13 \mathrm{mU} / \mathrm{L}$ (59-619). She had no biochemical evidence of diabetes insipidus (urine osmolality $280 \mathrm{mOsm} / \mathrm{kg}$, serum osmolality $310 \mathrm{mOsm} / \mathrm{kg}$ ) and there was no visual field defect.

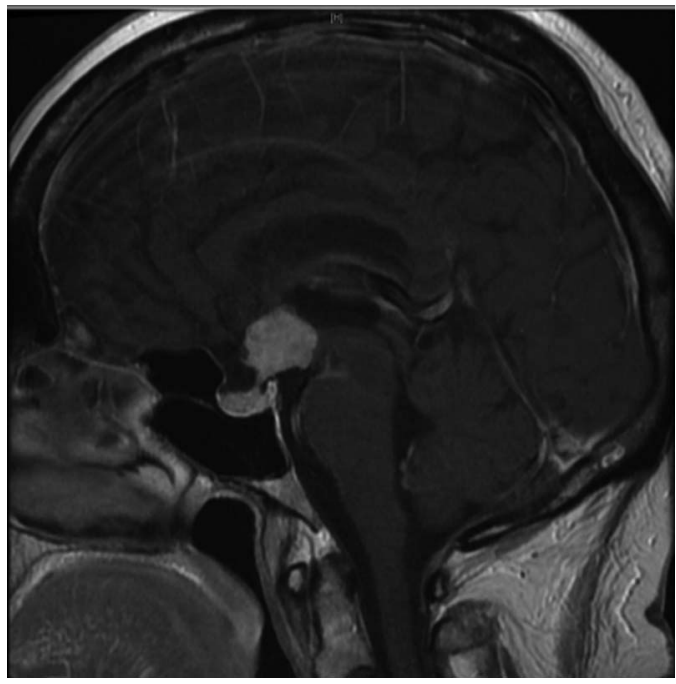

Figure 1 Sagittal MRI (T1 weighted with gadolinium) showing contrast-enhancing hypothalamic metastasis.
MRI (figure 1) revealed an enhancing lesion obliterating the hypothalamus with extension into the pituitary stalk. She was treated with palliative radiotherapy ( $30 \mathrm{G}$ in 10 fractions) to the lesion and hormone replacement with levothyroxine and hydrocortisone. Her lethargy and weight improved temporarily, but memory and cognitive difficulties persisted despite treatment. This could have been due to insufficient control of the intracranial metastases. Unfortunately, the patient's clinical condition worsened in the weeks following treatment, so no further MRI were performed, and she ultimately died from her systemic disease.

\section{Learning points}

- Panhypopituitarism can present with non-specific symptoms and signs in patients with cancer, and should be considered as part of a differential diagnosis.

- In patients with known malignancy presenting with symptoms of an endocrine disorder, brain metastases should be remembered as an uncommon cause.

Contributors ME wrote the manuscript and was involved in the patient care. TJ and NB were involved in the patient care and review and editing of the manuscript.

\section{Competing interests None.}

Patient consent Obtained.

Provenance and peer review Not commissioned; externally pee reviewed.

Copyright 2014 BMJ Publishing Group. All rights reserved. For permission to reuse any of this content visit http://group.bmj.com/group/rights-licensing/permissions.

BMJ Case Report Fellows may re-use this article for personal use and teaching without any further permission.

Become a Fellow of BMJ Case Reports today and you can:

- Submit as many cases as you like

- Enjoy fast sympathetic peer review and rapid publication of accepted articles

- Access all the published articles

- Re-use any of the published material for personal use and teaching without further permission

For information on Institutional Fellowships contact consortiasales@bmjgroup.com

Visit casereports.bmj.com for more articles like this and to become a Fellow 